\title{
SCIDiC
}

International Journal of Dentistry and Oral Science (IJDOS)

ISSN: 2377-8075

\section{Clinical Comparison Of Two Electronic Apex Locators In Working Length Determination As Compared To Conventional Radiography In Primary Molars}

Research Article

Pavithiraa Sankar ${ }^{1 *}$, Ganesh Jeevanandan ${ }^{2}$

${ }^{1}$ Postgraduate, Department of Pedodontics, Saveetha Dental College, Saveetha Dental College and Hospitals, Saveetha Institute of Medical and Technical Sciences, 162, Poonamallee High Road, Chennai 600077, Tamil Nadu, India.

${ }^{2}$ Reader, Department of Pedodontics, Saveetha Dental College, Saveetha Dental College and Hospitals, Saveetha Institute of Medical and Technical Sciences, 162, Poonamallee High Road, Chennai 600077, Tamil Nadu, India.

\section{Abstract}

\begin{abstract}
Aim: The aim of this study was to evaluate the effectiveness of two different types of electronic apex locators and conventional radiography for working length determination in primary teeth.

Materials and methods: A total of 50 primary teeth indicated for pulpectomy in children aged 4 to 9 years were randomly selected and subjected to working length determination using two varieties of electronic apex locators and conventional radiography. The data were then subjected to statistical analysis.

Results: The values obtained using the 2 electronic apex locators were similar but the values were not statistically significant in comparison to the conventional radiographic values. Children showed more positive behaviour on usage of electronic apex locators as compared to conventional radiography and was statistically significant.

Conclusion: conventional radiography and apex locators are equally effective in determining working length in primary teeth. The electronic apex locators were far better accepted by children than conventional radiography.
\end{abstract}

Keywords: Electronic Apex Locators; Conventional Radiography, Pulpectomy; Working Length.

\section{Introduction}

Pulpectomy of primary teeth is indicated when the radicular pulp tissue is necrotic.[1] Failure to determine the proper root canal working length during root canal treatment may compromise the treatment result.[2] The lack of patient's cooperation, limited access, anatomical variations, and complex anatomy of the primary roots defines the complex nature of endodontic treatment in young children $[3,4]$. Constant resorption and hard tissue deposition combined with the tortuous and peculiar morphology of primary molar root canal systems, [5] the size of the root canals, location of the apical foramina is continually altered making it difficult to determine the exact position of apical foramen 6,7$]$. One of the most important but still overlooked detail would be the possibility of overinstrumentation leading to periapical injury and in rare cases damage to the permanent successor germ $[8,9]$.

Behavior of the child is one of the most important factors de- ciding the success of the treatment. And increase in treatment duration most often leads to decrease in cooperative ability of the child. Moreover, having an anxiety free, relaxed child not only leads to an uneventful treatment procedure but also improves operator efficiency [10].

Conventional radiographic techniques have been used for decades to obtain information about root canal anatomy, working length and the surrounding soft tissues. Radiographic method described by Ingle is one of the most common and reliable methods used in determining the working length. The accurate determination of root canal length radiographically is hindered because of the anatomical variations, interference of anatomical structures or errors in projection [8]. Moreover, it is difficult to obtain a diagnostic radiograph in children because of poor patient cooperation and limited access to the mouth $[8,11]$. In addition, there is a radiation hazard, both, to the patient and the dental personnel. The observers' bias in radiographic interpretation may lead to errors [12].

\section{*Corresponding Author:}

Pavithiraa Sankar,

Postgraduate, Department of Pedodontics, Saveetha Dental College, Saveetha Dental College and Hospitals, Saveetha Institute of Medical and Technical Sciences, 162, Poonamallee High Road, Chennai 600077, Tamil Nadu, India.

E-mail:151911003.sdc@saveetha.com

Citation: Pavithiraa Sankar, Ganesh Jeevanandan. Clinical Comparison Of Two Electronic Apex Locators In Working Length Determination As Compared To Conventional Radiography In Primary Molars. Int J Dentistry Oral Sci. 2021;8(7):3146-3150. doi: http://dx.doi.org/10.19070/2377-8075-21000640

Copyright: Pavithiraa Sankar 2021 . This is an open-access article distributed under the terms of the Creative Commons Attribution License, which permits unrestricted use, distribution and reproduction in any medium, provided the original author and source are credited. 
Use of an electronic apex locator for determining WL has reduced radiation dosage and time [8]. In 1918, Custer was the first to develop the idea that root canal length could be estimated by the use of an electrical current. The electrical resistance between the periodontal ligament and oral mucosa has a constant value that could be measured using electronic apex locator [13].

Electronic apex locators (EAL) have been used in endodontic treatment for many years, especially in permanent teeth, and five generations of apex locators have been produced by manufacturers $[14,15]$. The use of EAL in primary teeth, however, is not universally accepted [16]. The literature does not indicate the differences when using the EAL in permanent and primary teeth [8], but it was concluded that electronic apex locators are safe, painless, and useful because they avoid unnecessary radiation [4].

A significant disadvantage of the previous generation devices is that they need to perform in relatively dry or in partially dried canals. In some cases, this necessitates additional drying. Also in heavy exudates or blood it becomes inapplicable [8, 17-19]. Both R SMART PLUS and the ProPexPixi Apex Locator (DentsplySirona, Maillefer) are 5 th generation apex locator that uses multi frequency technology to locate the apical foramen. Some new generation endo motors also come with the electronic apex locators attached and this further reduces the instrumentation time and thereby improves the patient cooperation.

To cope with the problems associated with previous generations of apex locators the 5th generation device uses a new measuring method that has been developed based on comparison of the data taken from the electrical characteristics of the canal and additional mathematical processing. It measures the capacitance and resistance of the circuit separately and is supplied with an inbuilt diagnostic table that includes statistics of the file. They have the best accuracy in any root canal condition (dry, wet, bleeding, saline, EDTA, $\mathrm{NaOCl}$ [ $[20,21]$. Hence even in mild resorption cases the reading will be accurate [22]. It is claimed to be less affected by electrical noises affecting other physical parameters, such as amplitude or phase of electrical signal [23]. However,in vivo studies to evaluate their accuracy in the primary dentition are limited.

This study is hence aimed at clinically comparing the two electronic apex locators in working length determination as compared to conventional radiography in primary molars.

\section{Materials And Methods}

This randomized clinical trial was conducted in children aged between 4 and 9 years with mandibular primary second molars scheduled for pulpectomy and accompanying their parents to the department of pediatric and preventive dentistry.

\section{Ethical approval}

The study was registered with the Institutional Review Board of the Saveetha Institute of Medical and Technical Sciences, Chennai, Tamil Nadu, India. Ethical approval was obtained from the Institutional Review Board of the SIMATS. Informed consent was obtained from all parents of the children before including them in the study. Informed consent was obtained from the par- ents/guardians of participating children prior to the treatment.

\section{Source of participants}

Children aged between 4 and 9 years were included. Mandibular primary second molars with nonrestorable crown structure, intracanal calcifications, extensive periapical/furcation radiolucency, mobility, twothird of the root resorption, and children with any underlying systemic disorders were excluded from the study. A preoperative radiograph was taken using bisecting technique to confirm the selection criteria.

\section{Clinical procedure}

After administration of local anesthesia the tooth was isolated with rubber dam. Access cavity was prepared and the coronal pulp tissue was removed using spoon excavator. Barbed broaches and $\mathrm{K}$ files were used to extirpate the pulp tissue from each root canal followed by rotary instrumentation. Care was taken not to penetrate the apex. The root canals were then irrigated with $1 \%$ sodium hypochlorite followed by sterile saline solution. The pulp chamber was dried using sterile cotton pellets.

Working length was then determined by conventional radiography and EALs in all the selected teeth.

\section{Working length determination by radiographic method}

Measurements were made from the preoperative radiograph using ISO 15 size files with rubber stoppers. With these measurements, files were inserted into the canals. In case of more than one canal on the same side different types of files were inserted in each canal for easy identification. Conventional intraoral periapical radiograph was taken using the bisecting angle technique. Cusp adjacent to the canal was taken as the occlusal reference. The files were removed and file length was determined using an endogauge. Ingle's method was followed for working length determination (file $1 \mathrm{~mm}$ shorter than the radiographic apex).

\section{Working length determination using electronic apex loca- tors}

Working length was determined clinically using PropexPixi (DentsplyMaillefer, Ballaigues, Switzerland) and R SMART PLUS apex locators as per the manufacturer's instructions. Both the EAL were used but first was chosen randomly.

\section{Working length determination using electronic apex locator}

The same K-file used in the radiographic method was attached to the file holder and the ground electrode was secured to the patient's labial commissure. The pulp chamber was dried using sterile cotton pellets. The file was advanced into the canal till the PropexPixi showed the 0.5 marking, indicating that the file was in the apical zone. The rubber stopper was adjusted at the same occlusal reference point as the radiographic method. The file was carefully withdrawn from the canal and the measurement was recorded using an endogauge. This procedure was followed for each canal.

\section{Assessment of behaviour}


Frankl'sbehaviour rating scale was used to check for the behavior of the child while using apex locators or using conventional radiography.

Pulpectomy treatment was completed in subsequent appointments.

\section{Statistical methods}

The data collected were statistically analyzed using the SPSS version 18.0 software (SPSS Inc., Chicago, IL, USA). One-way analyses of variance were used to test the difference between the EALs (PropexPixi and R SMART PLUS) and conventional radiography groups. Pearson correlation coefficient test was used to determine whether there was any correlation between the three measurements. The behavioral responses of the children to the three methods of working length determination were assessed using the Chi-square test. In all the above tests, $\mathrm{P}<0.05$ was taken to be statistically significant.

\section{Results}

A total of 50 teeth with 150 canals were evaluated in this study. 11 mandibular primary second molars included for working length determination were in 4-5-year-old children, 17 in 5-6-year-old children, 18 in 6-7-year-old children, 4 in 7-8-year-old children. Table 1 shows the means of working length obtained by conventional radiography and PropexPixi and R SMART PLUS apex locators. No statistically significant difference was detected between the three methods ( $>>0.05)$. Children showed more positive behaviour on usage of electronic apex locators as compared to conventional radiography and values were statistically significant.

\section{Discussion}

The accuracy of apex locators is higher when compared with that of the radiographic methods. Modern apex locators can locate not only the apical foramen but also, in contrast to radiographic methods, the apical constriction, which is an optimal endpoint for root canal preparation and filling [24]. In the present study, fifth generation apex locator was used which works on dual frequency type, and is considered best in any root canal condition. It provides the reader with a digital read out, graphic illustration and an audible signal. But it is also emphasized that the use of apex locator alone without the preoperative and postoperative radiographs is not a recommended practice due to the large number of variations in the tooth morphology, and medico legal record keeping requirements [25].

Kobayashi and Fan et al $[26,27]$ reported that the electroconductive solutions present inside the canal greatly reduce the impedance and therefore resulted in a tendency toward shorter measurements, whereas longer measurements were detected in the lower electroconductive solution. This is in agreement with other studies in which the accuracy of different brands of apex locators were evaluated in the presence of different irrigants, and a greater deviation from the actual WL was obtained with $\mathrm{NaOCl}$ [28].

Working length radiograph was taken using bisecting angle technique as it is the most common radiographic technique and the presence of a rubber dam, rubber dam clamp, and the root canal

Table 1.

\begin{tabular}{|c|c|c|c|c|}
\hline Root canal & $\begin{array}{l}\text { WL determination } \\
\text { method }\end{array}$ & $\mathrm{n}$ & mean & p \\
\hline \multirow[t]{3}{*}{ Mesio buccal } & $\begin{array}{l}\text { Conventional } \\
\text { radiography }\end{array}$ & 50 & 13.71 & \multirow[t]{3}{*}{0.801} \\
\hline & propexpixi & 25 & 13.45 & \\
\hline & R Smart Plus & 25 & 13.99 & \\
\hline \multirow[t]{3}{*}{ Mesio lingual } & $\begin{array}{l}\text { Conventional } \\
\text { radiography }\end{array}$ & 50 & 12.45 & \multirow[t]{3}{*}{0.677} \\
\hline & propexPixi & 25 & 12.33 & \\
\hline & R Smart Plus & 25 & 12.79 & \\
\hline \multirow[t]{3}{*}{ Distal } & $\begin{array}{l}\text { Conventional } \\
\text { radiography }\end{array}$ & 50 & 13.23 & \multirow[t]{3}{*}{0.594} \\
\hline & propexpixi & 25 & 13.87 & \\
\hline & R Smart Plus & 25 & 13.64 & \\
\hline
\end{tabular}

Table 2 .

\begin{tabular}{|c|c|c|c|c|c|c|c|}
\hline \multirow{2}{*}{ Age (years) } & \multirow{2}{*}{$\mathbf{N}$} & \multirow{2}{*}{$\begin{array}{c}\text { Working length } \\
\text { determination method }\end{array}$} & \multicolumn{4}{|c|}{ Frankl's behavior rating scale } & \multirow{2}{*}{ P - value } \\
\hline & & & -- & - & + & ++ & \\
\hline \multirow{3}{*}{$4-5$ years } & 11 & Conventional method & 3 & 4 & 3 & 1 & \multirow{3}{*}{0.01} \\
\hline & 5 & Propexpixi & 0 & 0 & 3 & 2 & \\
\hline & 6 & R Smart plus & 0 & 0 & 4 & 2 & \\
\hline \multirow{3}{*}{$5-6$ years } & 17 & Conventional method & 5 & 7 & 2 & 3 & \multirow{3}{*}{0.001} \\
\hline & 8 & Propexpixi & 0 & 0 & 5 & 3 & \\
\hline & 9 & R Smart plus & 0 & 0 & 7 & 2 & \\
\hline \multirow{3}{*}{$6-7$ years } & 18 & Conventional method & 2 & 6 & 9 & 1 & \multirow{3}{*}{0.001} \\
\hline & 9 & Propexpixi & 0 & 0 & 5 & 4 & \\
\hline & 9 & R Smart plus & 0 & 0 & 3 & 6 & \\
\hline \multirow{3}{*}{$7-8$ years } & 4 & Conventional method & 0 & 1 & 3 & 0 & \multirow{3}{*}{0.012} \\
\hline & 2 & Propexpixi & 0 & 0 & 2 & 0 & \\
\hline & 2 & R Smart plus & 0 & 0 & 1 & 1 & \\
\hline
\end{tabular}


instruments may complicate by impairing proper receptor positioning and aiming cylinder angulations with paralleling technique [29]. The radiographic working length produced by both paralleling and bisecting angle technique has been compared and concluded that comparable working lengths and the slightly better performance of the former would be clinically irrelevant [30].

Palatal and mesiobuccal roots of maxillary molars were associated with the highest incidence of inaccurate radiographic working length compared with other roots in vitro and in vivo [31, 32]. Hence only mandibular 1 st and 2 nd molars were included in the study.

In a previous study D'Assuncao evaluated 2 apex locators and found that they are reliable in finding the apical foramen [33]. Sadeghi in another study compared apex locators with conventional radiography in straight and curved canals and found apex locators are reliable in determining working length regardless of the curvature of the canals [34].

The behaviour of the child greatly affects the outcome of the treatment. It was found that childen found the electronic apex locators to be more comfortable as compared to the conventional radiographic methods. The placement of the film positioner was problematic in children with small mouth openings which could attribute to them finding the procedure uncomfortable and to some extent the negative behaviors [6].

Within the limits of this study, both electronic apex locators were able to determine the minor diameter within $\pm 0.5 \mathrm{~mm}$ therefore likely to provide clinically acceptable measurements. The $\mathrm{R}$ SMART PLUS is moreover a new instrument that has yet to be described in the literature. We find that this apex locator shows similar results and also poses a slight advantage over PropexPixi as the apex locator is attached to the endo motor thereby drastically reducing the working time.

\section{Conclusion}

Both the apex locators were as accurate as conventional radiography in determining working length in primary teeth; with no statistically significant difference between R Smart Plus and PropexPixi. R Smart Plus posed a slightly better advantage in children as the apex locator was built in with the endomotor. The electronic apex locators were far better accepted by children than conventional radiography.

\section{References}

[1]. Rajsheker S, Mallineni SK, Nuvvula S. Obturating Materials Used for Pulpectomy in Primary Teeth-A Mini Review. J Dent Craniofac Res. 2018;3(1):3.

[2]. D'Assunção FL, de Albuquerque DS, Salazar-Silva JR, de Queiroz Ferreira LC, Bezerra PM. The accuracy of root canal measurements using the Mini Apex Locator and Root ZX-II: an evaluation in vitro. Oral Surg Oral Med Oral Pathol Oral RadiolEndod. 2007 Sep;104(3):e50-3. PubmedPMID: 17709069.

[3]. Nelson-Filho P, Romualdo PC, Bonifácio KC, Leonardo MR, Silva RA, Silva LA. Accuracy of the iPex multi-frequency electronic apex locator in primary molars: an ex vivo study. IntEndod J. 2011 Apr;44(4):303-6. PubmedPMID: 21166827

[4]. Oznurhan F, Ünal M, Kapdan A, Ozturk C, Aksoy S. Clinical evaluation of apex locator and radiography in primary teeth. Int J Paediatr Dent. 2015 May;25(3):199-203. PubmedPMID: 25073636.
[5]. Ahmed HM. Anatomical challenges, electronic working length determination and current developments in root canal preparation of primary molar teeth. IntEndod J. 2013 Nov;46(11):1011-22. PubmedPMID: 23711096.

[6]. Nellamakkada K, Patil SS, Kakanur M, Kumar RS, Thakur R. A clinical evaluation of two electronic apex locators and conventional radiography in working length determination in primary molar and its influence on children's behavioral responses. J Indian SocPedodPrev Dent. 2020 AprJun;38(2):158-163. PubmedPMID: 32611862.

[7]. Kielbassa AM, Muller U, Munz I, Monting JS. Clinical evaluation of the measuring accuracy of ROOT ZX in primary teeth. Oral Surg Oral Med Oral Pathol Oral RadiolEndod. 2003 Jan;95(1):94-100. PubmedPMID: 12539034.

[8]. Leonardo MR, Silva LA, Nelson-Filho P, Silva RA, Raffaini MS. Ex vivo evaluation of the accuracy of two electronic apex locators during root canal length determination in primary teeth. IntEndod J. 2008 Apr;41(4):317-21. PubmedPMID: 18217990.

[9]. Poornima P, Ramchandani G, Neena IE, Roshan NM, Basavanna R, Nagaveni NB. Accuracy of Root ZX apex locator in primary teeth with different root canal irrigants: An in vivo study. Nigerian Journal of Experimental and Clinical Biosciences. 2015 Jan 1;3(1):24.

[10]. Pinkham JR. Observation and interpretation of the child dental patient's behavior. Pediatr Dent. 1979 Mar;1(1):21-6. PubmedPMID: 298744.

[11]. Mello-Moura AC, Moura-Netto C, Araki AT, Guedes-Pinto AC, Mendes FM. Ex vivo performance of five methods for root canal length determination in primary anterior teeth. IntEndod J. 2010 Feb;43(2):142-7. PubmedPMID: 20078703.

[12]. Lozano A, Forner L, Llena C. In vitro comparison of root-canal measurements with conventional and digital radiology. IntEndod J. 2002 Jun;35(6):542-50. PubmedPMID: 12190912.

[13]. Pommer O, Stamm O, Attin T. Influence of the canal contents on the electrical assisted determination of the length of root canals. J Endod. 2002 Feb;28(2):83-5. PubmedPMID: 11833694.

[14]. Bodur H, Odabaş M, Tulunoğlu O, Tinaz AC. Accuracy of two different apex locators in primary teeth with and without root resorption. Clin Oral Investig. 2008 Jun;12(2):137-41. PubmedPMID: 18027005.

[15]. Angwaravong O, Panitvisai P. Accuracy of an electronic apex locator in primary teeth with root resorption. IntEndod J. 2009 Feb;42(2):115-21. PubmedPMID: 19134039

[16]. Beltrame AP, Triches TC, Sartori N, Bolan M. Electronic determination of root canal working length in primary molar teeth: an in vivo and ex vivo study. IntEndod J. 2011 May;44(5):402-6. PubmedPMID: 21219365.

[17]. Gordon MP, Chandler NP. Electronic apex locators. IntEndod J. 2004 Jul;37(7):425-37. PubmedPMID: 15189431.

[18]. Nekoofar MH, Ghandi MM, Hayes SJ, Dummer PM. The fundamental operating principles of electronic root canal length measurement devices. IntEndod J. 2006 Aug;39(8):595-609. PubmedPMID: 16872454.

[19]. Ebrahim AK, Wadachi R, Suda H. Accuracy of three different electronic apex locators in detecting simulated horizontal and vertical root fractures. AustEndod J. 2006 Aug;32(2):64-9. PubmedPMID: 16869945.

[20]. Dimitrov S, Roshkev D. Sixth generation adaptive apex locator. Journal of IMAB-Annual Proceeding (Scientific Papers). 2009 Jan 1;15(2009):75-8.

[21]. Kovacević M, Tamarut T. Influence of the concentration of ions and foramen diameter on the accuracy of electronic root canal length measurement-an experimental study. J Endod. 1998 May;24(5):346-51. PubmedPMID: 9641111.

[22]. Khadse A, Shenoi P, Kokane V, Khode R, Sonarkar S. Electronic Apex Locators-An overview. Indian J ConservEndod. 2017 Apr;2:35-40.

[23]. Bonilla M, Sayin TC, Schobert B, Hardigan P. Accuracy of a new apex locator in ex-vivo teeth using scanning electron microscopy. EndodPract. 2014;16:14-20.

[24]. ElAyouti A, Dima E, Ohmer J, Sperl K, von Ohle C, Löst C. Consistency of apex locator function: a clinical study. J Endod. 2009 Feb;35(2):179-81. PubmedPMID: 19166768

[25]. Grimberg F, Banegas G, Chiacchio L, Zmener O. In vivo determination of root canal length: a preliminary report using the Tri Auto ZX apex-locating handpiece. IntEndod J. 2002 Jul;35(7):590-3. PubmedPMID: 12190898.

[26]. Kobayashi C. Electronic canal length measurement. Oral Surg Oral Med Oral Pathol Oral RadiolEndod. 1995 Feb;79(2):226-31. PubmedPMID: 7614187.

[27]. Fan W, Fan B, Gutmann JL, Bian Z, Fan MW. Evaluation of the accuracy of three electronic apex locators using glass tubules. IntEndod J. 2006 Feb;39(2):127-35. PubmedPMID: 16454793.

[28]. Ozsezer E, Inan U, Aydin U. In vivo evaluation of ProPex electronic apex locator. J Endod. 2007 Aug;33(8):974-7. PubmedPMID: 17878086.

[29]. White S. Benign tumor of jaw. Oral radiology. Principles and interpretation. 2004:410-58.

[30]. Joshua Moshonov DM, Slutzky-Goldberg I, RonitMaor DM, Boaz Shay 
DM, Peretz B. In vivo evaluation of Apex NRG, a new apex locator, and its comparison with Root ZX. ENDODONTIC PRACTICE. 2005 Nov.

[31]. Alothmani OS, Friedlander LT, Chandler NP. Radiographic assessment of endodontic working length. Saudi Endodontic Journal. 2013 May 1;3(2):57.

[32]. Saraf PA, Ratnakar P, Patil TN, Penukonda R, Kamatagi L, Vanaki SS. A comparative clinical evaluation of accuracy of six apex locators with intraoral periapical radiograph in multirooted teeth: An in vivo study. J Conserv Dent. 2017 Jul-Aug;20(4):264-268. PubmedPMID: 29259365.
[33]. D'Assunçấo FL, de Albuquerque DS, de Queiroz Ferreira LC. The ability of two apex locators to locate the apical foramen: an in vitro study. J Endod. 2006 Jun;32(6):560-2. PubmedPMID: 16728251.

[34]. Sadeghi SH, ABOU ALGHASEMI M. A comparison between the Raypex5 apex locator and conventional radiography for determining working length of straight and curved canals. 